\title{
The Triumph of Venus
}




\section{PHILOSOPHY, SOCIAL THEORY, AND THE RULE OF LAW}

\section{General Editors}

Andrew Arato, Seyla Benhabib, Ferenc Fehér, William Forbath, Agnes Heller, Arthur Jacobson, and Michel Rosenfeld

1. William Rehg, Insight and Solidarity: A Study in the Discourse Ethics of Jürgen Habermas

2. Alan Brudner, The Unity of the Common Law: Studies in Hegelian Jurisprudence

3. Peter Goodrich, Oedipus Lex: Psychoanalysis, History, Law

4. Michel Rosenfeld, Just Interpretations: Law between Ethics and Politics 5. Jeanne Lorraine Schroeder, The Vestal and the Fasces: Hegel, Lacan, Property, and the Feminine

6. Michel Rosenfeld and Andrew Arato, editors, Habermas on Law and Democracy: Critical Exchanges

7. Desmond Manderson, Songs without Music: Aesthetic Dimensions of Law and Justice

8. Arthur J. Jacobson and Bernhard Schlink, editors, Weimar: A Jurisprudence of Crisis

9. Rainer Forst, Contexts of Justice: Political Philosophy Beyond Liberalism and Communitarianism. Translated by John M. M. Farrell.

10. Jeanne Lorraine Schroeder, The Triumph of Venus: The Erotics of the Market 


\title{
The Triumph of Venus
}

The Erotics of the Market

\author{
Jeanne Lorraine Schroeder
}


University of California Press

Berkeley and Los Angeles, California

University of California Press, Ltd.

London, England

(C) 2004 by the Regents of the University of California

Library of Congress Cataloging-in-Publication Data

Schroeder, Jeanne Lorraine.

The triumph of Venus : the erotics of the market / Jeanne Lorraine Schroeder.

p. cm.-(Philosophy, social theory, and the rule of law ; 10)

Includes bibliographical references and index.

ISBN 0-520-23431-6 (cloth : alk. paper)

1. Law and economics-Psychological aspects-Philosophy. 2.

Sociological jusrisprudence. 3. Feminist jurisprudence. 4. Economic man. 5. Utilitarianism. 6. Romanticism. 7. Erotica. 8. Venus (Roman deity) I. Title. II. Series.

$\mathrm{K}_{4} 87 . \mathrm{E} 3 \quad \mathrm{~S}_{3} 8 \quad 2004$

$34 \mathrm{o}^{\prime} .115-\mathrm{dc} 21$

$200301277^{\circ}$

Manufactured in the United States of America

$\begin{array}{llllllllll}13 & 12 & 11 & 10 & 09 & 08 & 07 & 06 & 05 & 04\end{array}$

$\begin{array}{llllllllll}10 & 9 & 8 & 7 & 6 & 5 & 4 & 3 & 2 & 1\end{array}$

The paper used in this publication meets the minimum requirements of ANSI/NISO Z39.48-1992 (R 1997) (Permanence of Paper). 
For my mother 
This page intentionally left blank 